\title{
Soybean and babassu biodiesel production: a laboratory scale study and an exergy analysis approach
}

\author{
Antônio Alison da Silva Mamede ${ }^{1}$, Ada Amélia Sanders Lopes ${ }^{1}$, \\ Rosali Barbosa Marques ${ }^{2}$, Jackson Queiroz Malveira ${ }^{2}$, \\ Maria Alexsandra de Sousa Rios ${ }^{3}$
}

\author{
${ }^{1}$ Universidade da Integração Internacional da Lusofonia Afro-Brasileira - Campus dos Palmares, CEP: 62785-000, \\ Acarape, CE, Brasil. \\ ${ }^{2}$ Núcleo de Tecnologia Industrial do Ceará - Larbio/NUTEC, Pici, CEP: 60440-552, Fortaleza, CE, Brasil. \\ ${ }^{3}$ Universidade Federal do Ceará - GRINTEQUI/DEM/CT, Campus do Pici, Bloco 714, CEP: 60455-760, Fortaleza, CE, \\ Brasil. \\ e-mail: mamede.engenergias@gmail.com,ada@unilab.edu.br, rosalimarquess@gmail.com, \\ jackson.malveira@nutec.ce.gov.br, alexsandrarios@ufc.br
}

\begin{abstract}
The emission of gases from the fleet of vehicles is one of the main sources of the environmental impact of the planet. Reversing this scenario, environmental awareness and a search for alternative sources of energy has been growing exponentially in recent years. In this context, the production of biofuels presents itself as an alternative for the lowest environmental impact, energy, and economy, with emphasis on biodiesel. The scale of production of this biofuel, the options related to the raw materials and their conditions are intertwined with the energy and exergetic efficiencies of the process. Therefore, no work was constructed as an analysis of the biodiesel production processes of soybeans and babassu, in which they were conducted on a laboratory scale. According to the results, the production of soybean biodiesel arose in exergetic efficiency of $73.25 \%$ and the production of biodiesel from babassu of $74.72 \%$.
\end{abstract}

Keywords: Biodiesel, Babassu oil, Soybean oil, Exergy, Transesterification.

\section{INTRODUCTION}

Today, growing demand for energy is one of the biggest problems facing nations. Environmental impact, high oil prices and accelerated development of emerging countries are contributing factors to concerns related to the greater world energy need [1], which still today come mainly from non-renewable sources such as oil, natural gas, and coal. The burning of fuels derived from these sources generates chemical compounds that have polluting potential and thus, impact the environment, a fact that has motivated society in the search for solutions to minimize or even eradicate this problem [2].

Among the alternatives found to solve this problem, we highlight the research related to biofuels, taking as an example, biodiesel [3]. This fuel has advantages when compared to petrodiesel, as derived from renewable sources, biodegradable, non-toxic, possessing significant lubricity and practically free of sulfur and aromatics [4]. In this way, the use of biomass for energy production reduces the emission of Greenhouse gases and promotes sustainable development based on the decrease in the use of fossil fuels [5].

In this scenario, the use of biodiesel is growing throughout the world, as it presents a productive chain with promising potential in the economic, social and environmental sectors. Thus, this biofuel opens opportunities for the generation of employment in the countryside and valorization of rural labor, favoring the industrial sector of biodiesel production [6].

Although the biodiesel production industries show a positive breakthrough, there are points that need attention such as the competition of the food market for cultivable areas, and the non-reduction of emission greenhouse gases, depending on the technique used in the harvest. In this context, new biofuel production technologies have arisen that put an end to these limitations. These new processes are called second generation biofuels [7]. For the production of second and third biodiesel generation, different technologies are used [8]. Second-generation biodiesel is produced by the raw material that is not used to human consumption, for example, jatropha oil [9]. In this scenario, other raw materials such as single-celled algae gain space because, 
in addition to being efficient microorganisms in the process of photosynthesis, they do not compete with food market or agricultural areas. However, the cropping processes, the efficient methods of oil isolation, and nutrients for crops are limitations to be overcome in order to reduce the final costs [10].

As far as the productive sector is concerned, the European Union is the world's largest producer of biodiesel, with a production capacity of 24.9 billion liters in 2016 and approximately 25.5 billion liters in 2017 [11]. Some of the main biodiesel producing countries are Germany, France, USA, Brazil, Argentina, the Netherlands, and Indonesia [12].

Recently, a survey conducted by the International Energy Agency (IEA), the International Energy Agency (IEA), indicates that Brazil is the country that uses biomass most in energy production, with $16 \%$ of world use in the industry. Then there are the USA (9\%) and Germany (7\%). According to data from the IEA, the 15 countries at the top of the list account for $65 \%$ of the global use of biomass in the energy matrix. Currently, biomass accounts for around 10\% of global energy production [13].

With respect to the definition of biodiesel, it is characterized by a mixture of mono-alkyl esters of fatty acids obtained by the transesterification reaction of triglycerides (TG) using short chain alcohols as transesterifying agent (methanol or ethanol) and sodium or potassium hydroxide as the catalyst [14].The biodiesel production process is performed through chemical reactions, in which transesterification is the most used due to the higher yield and lower energy consumption [15]. Currently, the total cost in biodiesel production is attributed to the system used and raw materials. An alternative to reduce costs in production is the optimization of the efficiency of the catalyst used in the process [16].

In general, the catalysts used in the production of biodiesel are alkalis, acids, oxides or enzymes [17]. The alkalis and acids are more used and categorized as homogeneous catalysts, and oxides categorized as heterogeneous catalysts [18]. Among the catalysts used, the sodium hydroxide and potassium hydroxide due to available and inexpensive, are the most used catalysts [19-20].

Although acid catalysts are effective in transesterification, they can promote contamination problems to the environment, if there is no treatment of the products and byproducts of the reaction. On the other hand, the use of heterogeneous catalysts, in transesterification, can be simplified separation and purification of the products and byproducts, consequently, reduce the waste generation [16]. Due to the production of biodiesel represent a promising alternative to meet the growing demand energy, technological routes for the production of this fuel have been studied, in the last years.

Beyond the chemical route, the enzymatic and the nano-catalysis route have been aroused great interest. With relation to enzymatic route, although it is considered a process of high cost, it may present advantages, becoming feasible for industry application. About the nano-catalysis, in general, is a cheaper, simpler and cleaner process. However, it has the disadvantage of the nanotoxicity for human and environment [21]. Figure 1 shows the general equation of the transesterification reaction of a triglyceride [22].

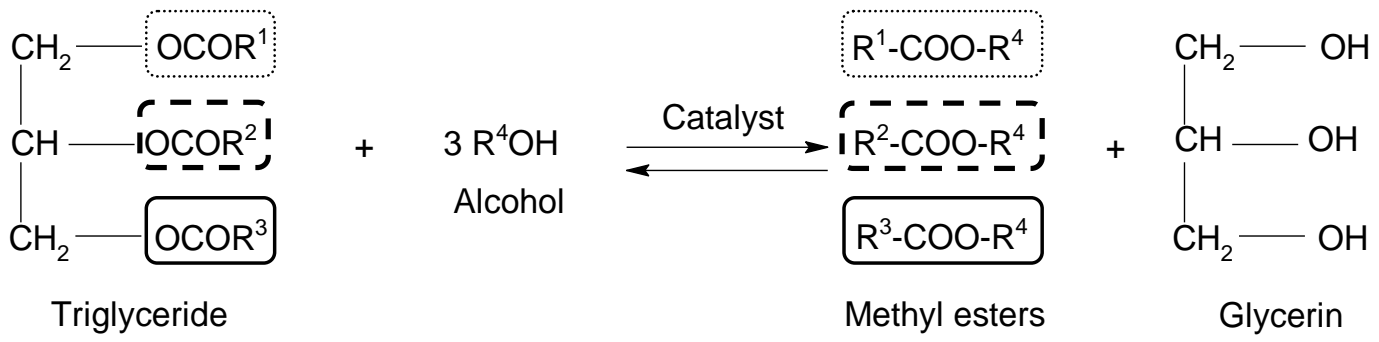

$\mathrm{R}^{1}, \mathrm{R}^{2}, \mathrm{R}^{3}$ : represent the carbon chains of fatty acids of soybean and babassu oils.

$\mathrm{R}^{4}: \mathrm{CH}_{3}$

Figure 1: General equation for a transesterification reaction

The general precession of transesterification, while being consecutive, is a molar measure of triglyceride (TG) reacted with three moles of alcohol for the filtration of three molar esters and glycerol. [22] In Brazil, soybeans are the main raw material for biodiesel production. In this sense, the diversification of greases would be an interesting alternative to leverage the biodiesel production sector and the productive chains of other oilseeds. One option would be to use the oil extracted from the Babassu coconut, which represents important biomass obtained in the states of Maranhão, Piaui, and Ceara.

As regards the evaluation of the environmental impacts generated by fuels, in addition to the emission of greenhouse gases, the energy and exergetic efficiency of their production processes are essential to research [23], since in the industrial stages of obtaining them, part of the energy is lost in the form of heat and 
can be quantified through energy and exergetic balances and by determining the magnitude of the irreversibility's [24].

The sources of irreversibilities in production processes, which impact energy efficiency, represent losses in energy conversions and, consequently, an increase in production costs [25]. In this sense, the evaluation of the exergy, that is, the determination of the real capacity of performing a mechanical work of a system presents itself as an important parameter of analysis of thermal systems.

According to the literature [26], exergy is defined as the maximum "useful" energy that can be "extracted" from a system or process and is determined by thermodynamic principles [27-28]. The exergy analysis method is particularly appropriate to maximize the efficient use of energy since it allows the determination of tailings and losses in terms of location, type, and actual values.

The concept of exergy is closely linked to the foundations of the Second Law of Thermodynamics [29] and is determined as the potential for generating physical work of a system until it reaches equilibrium with the environment [30]. Thus, the exergy calculation provides detailed information about wasted energy in a process, through the calculation of performance [31-34], and thus, can contribute to the verification and quantification of losses and also indicate improvements that can be made in the process of biodiesel production.

In this sense, the work presents the exergy analysis of the biodiesel production processes of soybeans and babassu, performed in laboratory scale. Biofuels were obtained by transesterification via basic catalysis, with methanol as the transesterifying agent. The main objective of this work was to analyze the exergy from the vegetable raw materials - soy oils and babassu -, in order to determine the efficiency of each stage of the process, in order to contribute with the current context of sustainability and foment the use of renewable energy sources.

\section{MATERIALS AND METHODS}

The soybean and babassu oils were acquired at local markets of Fortaleza and Teresina, Brazil. Analytical grade methanol $(99.8 \%$ ) and potassium hydroxide $(85.0 \%)$ were supplied by Synth and Vetec, respectively. All measured properties were performed using standard methods of the American Oil Chemists' Society (AOCS) [35].

\subsection{Biodiesel Production}

Before transesterification reactions initiate the acidity indexes of oils were determined according to the American Oil Chemists' Society (AOCS), Cd 3d-63 method [36]. The procedure was performed in triplicate. After that, the soybean and babassu biodiesels were produced by transesterification reactions. In each reaction was used $200 \mathrm{~g}$ of oil. To calculate the volume of methanol and base catalyst (potassium hydroxide $(\mathrm{KOH}))$, Equations 1 and 2 were used [36-37].

$$
\begin{aligned}
& \text { Volume }_{\text {methanol }}=\frac{20 \% \times \text { Oil mass }}{\text { Absolute density of methanol }} \\
& \text { Mass }_{\text {catalyst }}=\text { oil mass } x\left(\frac{\% \mathrm{KOH}}{100}+\frac{\text { Acidity index }}{1000}\right) \times \frac{1}{0.85}
\end{aligned}
$$

$\% \mathrm{KOH}=$ mass percentage of $\mathrm{KOH}$ and 0.85 is the purity of the $\mathrm{KOH}$.

The volume of methanol used in each reaction was $20 \mathrm{~mL}$. The catalyst mass was $1.48 \mathrm{~g}$ for soybean oil and $1.46 \mathrm{~g}$ for babassu oil. After that, the oils were heated to $60{ }^{\circ} \mathrm{C}$, and subsequently, the methanol and the $\mathrm{KOH}$ were added in both reactions. The temperature was controlled by a thermostatic bath and did not exceed $60{ }^{\circ} \mathrm{C}$, the reaction time was $60 \mathrm{~min}$. At the end of the processes, the reaction systems were transferred to separation funnels to obtain the ester phase (upper) and glycerol phase (lower). The separation processes occurred in $60 \mathrm{~min}$. Subsequently, the phases composed of fatty acid methyl ester blends were washed and dried. Three washing processes were performed using $20 \mathrm{~g}$ of distilled water in each step, which corresponds to $10 \%$ of the mass of oil used in each reaction. The last step of wash was performed with distilled water at $90{ }^{\circ} \mathrm{C}$. In the end, the samples were heated at $105^{\circ} \mathrm{C}\left( \pm 5^{\circ} \mathrm{C}\right)$ for $30 \mathrm{~min}$. 
Elemental Analysis is used to determine the percentages of carbon, hydrogen, and nitrogen in a sample. This technique is based on the Pregl-Dumas method, which consists of the combustion of the sample. The gases resulting from the combustion are quantified in a thermal conductivity detector (TCD). Oxygen percentage is determined by difference. The determinations were performed using a Perkin-Elmer 2400 CHN Elemental Analyzer.

\subsection{Higher heating value (HHV)}

The Higher Heating Value (HHV) is the heat produced by the complete combustion of a substance at constant volume, under specified conditions, with the products returning to a temperature of $25^{\circ} \mathrm{C}$ and considering the latent heat of vaporization of the water on the combustion's products [38].

For determination of the HHV of fuel, an adiabatic calorimeter pump was used. The equipment is basically composed of a combustion chamber, where the reagents are placed. In this work, the HHV determinations were performed using IKA C200 calorimeter to burn the samples under an oxygen atmosphere (99.8 $\%)$. The experimental procedure contemplated international standards such as: DIN 51900, BS 1016 part S 1077, ASTM D 5865, ASTM D 240-87, ASTM E711-87, ISO 1928-1976 and ASTM D1989-91.

\subsection{Exergy Analysis}

In our study, the physical exergy, and the exergies of the kinetic and potential energy were neglected (except the exergy of the electrical equipment) once that, the processes production of biodiesel were carried out in batch reactor of $2 \mathrm{~L}$ - laboratory scale -, and did not occur mass flow through the boundaries of the system, see Equation 3 [39].

$E T=E p+E k+E F+E C H$

To obtain the exergy analyses of the processes, it was necessary to determine the chemical exergy (each) of the compounds of the reactions. This parameter was calculated by the product of the Lower Heating Value (LHV), and dimensionless coefficient $(\beta)$, Equation 4 [39-40].

$e c h=\beta . \mathrm{LVH}$

The LHV and dimensionless coefficient $(\beta)$ were determined by Equations 5 and 6, respectively.

$\beta=1,0374+0,0159 \frac{H}{C}+0,0567 \frac{0}{C}$

$\mathrm{H}=$ Hydrogen $; \mathrm{C}=$ Carbon; $\mathrm{O}=$ Oxygen .

$\mathrm{LHV}=\mathrm{HHV}-0,0894 * 2442,3 * H$

$L H V=$ Lower Heating Value

$H H V=$ Higher Heating Value

$2,442.3 \mathrm{~kJ} / \mathrm{kg}=$ enthalpy of vaporization of water ( 1 bar pressure).

To calculate the exergy efficiency, they were considered the exergy inputs $\left(e_{e}\right)$ and exergy outputs $\left(e_{s}\right)$ of the systems [37-38], see Equation 7.

$$
\eta=\frac{e_{B}}{e_{e}}
$$

$e_{s}=$ exergy input

$e_{e}=$ exergy output

\section{RESULTS AND DISCUSSION}

The exergy analysis of the soybean biodiesel production (SB) and of the babassu biodiesel production (BB) were carried out. To calculate the chemical exergy of the oils and biodiesels, it was necessary to quantify the percentages of carbon, hydrogen, and oxygen by elemental analysis (see Table 1) and to determine Higher Heating Value (HHV) and the Lower Heating Value (LHV). 
Table 1: Elemental composition of the soybean and babassu oils and their biodiesel.

\begin{tabular}{c|c|c|c}
\hline Samples & $\mathbf{C ~ ( \% )}$ & $\mathbf{H}(\%)$ & $\mathbf{O}(\%)$ \\
\hline SB $^{*}$ & 79.3 & 13.2 & 7.68 \\
\hline SBB** & 73.8 & 13.2 & 13.0 \\
\hline Soybean oil & 77.83 & 11.5 & 10.67 \\
\hline Babassu oil & 75.0 & 11.7 & 13.3 \\
\hline
\end{tabular}

*Soybean Biodiesel (SB). **Babassu Biodiesel (BB)

From the results of the elemental analysis, it was possible to calculate the values of LHV (Equation 6). HHV data were obtained from the calorimeter pump. The HHV and LHV data are shown in Table 2.

Table 2: HHV and LHV of the soybean and babassu oils and their biodiesel.

\begin{tabular}{c|c|c|c|c}
\hline Parameter & BS $^{*}$ & BB $^{* *}$ & SO $^{\text {***}}$ & BO $^{\text {****}}$ \\
\hline HHV $(\mathrm{kJ} / \mathrm{kg})$ & $40,187.50$ & $39,152.45$ & $39,417.46$ & $38,382.80$ \\
\hline LHV $(\mathrm{kJ} / \mathrm{kg})$ & $37,305.39$ & $36,270.34$ & $36,906.53$ & $35,828.20$ \\
\hline
\end{tabular}

*Soybean Biodiesel (SB) **Babassu Biodiesel (BB). ***Soybean Oil (SO) ****Babassu Oil (BO)

Table 3 shows the consumption of electricity, the time of use and the exergy of the equipment used. The coefficient of electric energy is considered 1 , so, $1 \mathrm{~kJ}$ of electric energy corresponds to an exergy flux of $1 \mathrm{~kJ}[39-41]$.

Table 3: Exergy of the equipment used.

\begin{tabular}{c|c|c|c}
\hline Equipment & Consumption (W) & Time (s) & Exergy (MJ) \\
\hline Magnetic Stirrer with Heating Plate & 650 & 3,600 & 2.34 \\
\hline Total & 650 & 3,600 & 2.34 \\
\hline
\end{tabular}

Tables 4 and 5 show chemical exergy, the mass, and the exergy of each reagent used in the biodiesel productions. To determine the exergy a calculation was made considering the product of the chemical exergy $(\mathrm{MJ} / \mathrm{kg})$ with the mass $(\mathrm{kg})$. So, the reagent exergy (MJ) was obtained. The highest chemical exergy was attributed to the soybean oil $(38.75 \mathrm{MJ} / \mathrm{kg})$. The babassu oil showed chemical exergy of $37.62 \mathrm{MJ} / \mathrm{kg}$, and the chemical exergy of the methanol $(22.14 \mathrm{MJ} / \mathrm{kg})$ and potassium hydroxide $(8.67 \mathrm{MJ} / \mathrm{kg})$ were obtained according to Arredondo [40].

Table 4: Reagent exergy used in soybean biodiesel production.

\begin{tabular}{c|c|c|c}
\hline Reagents & Chemical exergy (MJ/kg) & Mass (kg) & Reagent exergy (MJ) \\
\hline Soybean oil & 38.75 & 0.2 & 7.75 \\
\hline Methanol & $22.14^{*}$ & 0.04 & 0.886 \\
\hline KOH & $8.67^{*}$ & 0.0015 & 0.013 \\
\hline Total & 69.56 & 0.2415 & 8.649 \\
\hline
\end{tabular}

*According to Arredondo, 2009 [40].

Table 5: Reagent exergy used in babassu biodiesel production.

\begin{tabular}{c|c|c|c}
\hline Reagents & Chemical exergy (MJ/kg) & Mass (kg) & Reagent exergy (MJ) \\
\hline Babassu oil & 37.62 & 0.2 & 7.52 \\
\hline Methanol & $22.14^{*}$ & 0.04 & 0.886 \\
\hline KOH & $8.67 *$ & 0.0015 & 0.013 \\
\hline Total & 68.43 & 0.2415 & 8.419 \\
\hline
\end{tabular}

\footnotetext{
*According to Arredondo, 2009 [38].
}

Tables 6 and 7 show chemical exergy, the mass, and the exergy of each product and by-product obtained in the biodiesel productions. The chemical exergy $(\mathrm{MJ} / \mathrm{kg})$ of the glycerol was obtained from the literature [28, 39-42]. 
Table 6: Product and by-product exergy obtained in the soybean biodiesel production.

\begin{tabular}{c|c|c|c}
\hline Samples & Chemical exergy (MJ/kg) & Mass (kg) & $\begin{array}{c}\text { Product and by-product exergy } \\
\text { (MJ) }\end{array}$ \\
\hline Soybean biodiesel & 39.00 & 0.1960 & 7.64 \\
\hline Glycerol & $16.26^{*}$ & 0.0244 & 0.397 \\
\hline Total & 55.26 & 0.2204 & 8.04 \\
\hline
\end{tabular}

*According to Oliveira et al., 2010 [28].

Table 7: Product and by-product exergy obtained in the babassu biodiesel production.

\begin{tabular}{c|c|c|c}
\hline Samples & Chemical exergy (MJ/kg) & Mass $\mathbf{( k g )}$ & $\begin{array}{c}\text { Product and by-product exergy } \\
\text { (MJ) }\end{array}$ \\
\hline Babassu biodiesel & 38.08 & 0.1953 & 7.44 \\
\hline Glycerol & $18.5^{*}$ & 0.0326 & 0.603 \\
\hline Total & 56.58 & 0.2279 & 8.04 \\
\hline
\end{tabular}

*According to Arredondo, 2009 [38].

Equation 7 was possible to calculate the exergy efficiency of the processes. The exergy inputs considered were the sum of the exergy of the equipment and the exergy of the reagents used. The exergy outputs considered were the sum of the products and by-products obtained.

For the soybean biodiesel production, the exergy input was $10.99 \mathrm{MJ}$, and the exergy output was 8.05 $\mathrm{MJ}$, with a difference of $2.94 \mathrm{MJ}$, while the babassu biodiesel production showed an exergy input of 10.76 $\mathrm{MJ}$, and an exergy output of $8.04 \mathrm{MJ}$, with a difference of $2.72 \mathrm{MJ}$. Table 8 shows the exergetic efficiencies calculated.

Table 8: Exergy efficiency of soybean and babassu biodiesel productions.

\begin{tabular}{c|c|c}
\hline \multirow{2}{*}{ Parameter } & \multicolumn{2}{|c}{ Results (\%) } \\
\cline { 2 - 3 } & SB* & BB** \\
\hline Exergy efficiency & 73.25 & 74.72 \\
\hline
\end{tabular}

* Soybean biodiesel (SB). ** Babassu biodiesel (BB)

The exergy efficiency of soybean biodiesel was $73.25 \%$. This result corroborates with the results obtained by Silva (2017) [43], which obtained an exergetic efficiency of approximately $72 \%$, for the soybean biodiesel. For the babassu biodiesel, the exergy efficiency was $74.72 \%$. This result is lower than the result determined by Ferreira (2014), which obtained an exergy efficiency of $96 \%$ [42].

According to results, it is possible to infer that the babassu biodiesel production presented an exergy efficiency slightly higher than the soybean biodiesel production. This difference can be attributed to losses related to heat and non-reactive residues of the reactions as well as the irreversibilities that occur in the processes.

\section{CONCLUSIONS}

The soybean and babassu biodiesels were produced by transesterification reactions in a batch reactor, on a laboratory scale. The results of exergy analysis showed that the babassu biodiesel production was slightly higher $(74.72 \%)$ than the soybean biodiesel production $(73.25 \%)$. This difference can be attributed to heat losses, the non-reactive residues of the reactions, and the irreversibilities of the systems.

According to results, it was possible to conclude that the exergy analysis is very important to the evaluation of biodiesel production processes, once that the exergy allows identifying and discussing the aspects that cause useful energy loss. Although irreversibilities were verified in transesterification reactions, the exergy efficiencies were satisfactory and presented compatible results. On the biodiesel production, the variation of parameters such as temperature, time, agitation and the stoichiometric ratio can improve the exergy efficiency of the process and as a consequence to improve energy utilization.

\section{ACKNOWLEDGMENTS}

The authors acknowledge CNPq (406697/2013-2, 459355/2014-7, and 308280/2017-2), CAPES, FINEP, and FUNCAP (Process AEP-0128-00220.01.00/17) for financial support. 


\section{BIBLIOGRAPHY}

[1] ENCINAR, J.M, GONZÁLES, J.F, RODRÍGUES, J.J, TEJEDOR, A., "Biodiesel fuels from vegetable oils: transesterification of Cynara cardunculus L. oils with etanol", Energy Fuels, n. 16, pp. 443-450, 2002.

[2] MONYEM, A., VAN GERPEN, J.H. "The effect of biodiesel oxidation on engine performance and emissions”, Biomass Bioenergy, n. 20, pp. 317-25, 2001.

[3] GOBIKRISHNAN, S., PARK, JH., PARK, SH. et al., "Sonication-assisted production of biodiesel using soybean oil and supercritical methanol”, Bioprocess Biosyst Eng., n. 36, pp. 705-12, 2013.

[4] MARTINI, N., SHELL, J.S. Plant Oils as Fuels-Present State of Science and Future Development, Springer, Berlin, p. 276, 1998.

[5] DANTAS, J., LEAL, E., MAPOSSA, A.B., et al., “ Síntese, caracterização e performance catalítica de nanoferritas mistas submetidas a reação de transesterificação e esterificação via rota metílica e etílica para biodiesel”, Revista Matéria, v. 21, n.4, pp. 1080-1093, 2016

[6] HEO, SW., RYU, BG., NAM, K. et al. "Simultaneous treatment of food-waste recycling wastewater and cultivation of Tetraselmis suecica for biodiesel production", Bioprocess Biosyst Eng., n. 38, pp. 1393-98, 2015.

[7] TAHER, D.M., Biodiesel de microalgas cultivadas em dejeto suíno biodigerido, Dissertação de mestrado UFPR, Curitiba, 2013

[8] GOLDENBERG, J. "Programa de bioenergia do estado de São Paulo", In: Conferência Nacional de Bioenergia. São Paulo, 2007. Org. Francisco Costa. USP - CCS - Coordenadoria de comunicação social, 2007.

[9] DAMASCENO, C. Etanol de segunda geração: nova possibilidade de combustível renovável. Disponível em: <http://www.noticiasagricolas.com.br/noticias/sucroenergetico/ 105842-etanol-de-segundageracao-nova-possibilidade-de-combustivel-renovavel.html\#.VFef5_nF8QU>. Acesso em: 03 Nov. 2014.

[10] AHMAD, A.L., YASIN, N.H.M., DEREK, C.J.C., et al., “ Microalgae as a sustainable energy source for biodiesel production: a review", Renewable and Sustainable Energy Reviews, v. 15, p. 584593, 2011.

[11] United States Department of Agriculture. Foreign Agricultural Service. Global agricultural information network. EU-28 Biofuels annual, 2015. http://www.fas.usda.gov/data/eu-28-eu-biofuels-annual (accessed 20 May 2018).

[12] The Statistics Portal, 2015. The world's biggest biodiesel producers in 2015. http://www.statista.com/ statistics/271472/biodiesel-production-in-selected-countries (accessed 15 April 2018).

[13] UDOP - União dos produtores de bioenergia. http://udop.com.br/index.php?item=noticias\&cod= 1153694 (accessed 21 May 2018).

[14] SOLTANI, S., RASHID, U., YUNUS, R., TAUFIQ-YAP, Y.H. "Synthesis of Biodiesel through Catalytic Transesterification of Various Feedstocks using Fast Solvothermal Technology: A Critical Review”, Catalysis Reviews - Science and Engineering, v. 57, pp. 1-29, 2015.

[15] CORDEIRO, C.S., SILVA, F.R., WYPYCH, F., RAMOS, L.P. "Heterogeneous catalysts for biodiesel production”, Quím. Nova, São Paulo, v. 34, n.3, 2011.

[16] TALHA, N. S., SULAIMAN, S. “Overview of catalysts in biodiesel production. Arpn”, Journal of Engineering and Applied Sciences, v. 11, n. 1, Jan. 2016.

[17] CANAKCI, M., VAN GERPEN, J. "Biodiesel Production via Acid Catalysis",Trans Am Soc Agric Eng, v. 42, pp. 1203-1210, 1999.

[18] MA F., HANNA M. A. "Biodiesel production: a review”, v. 70, pp. 1-15, 1999.

[19] ZAKARIA, R., HARVEY, A. P. "Direct production of biodiesel from rapeseed by reactive extraction/in situ transesterification," Fuel Process. Technol., v. 102, n. 2012, pp. 53-60, Oct. 2012.

[20] CHEN, K.T., WANG, J.X., DAI Y.M., et al.,"Rice husk ash as a catalyst precursor for biodiesel production”, J. Taiwan Inst. Chem. Eng., v. 44, n. 4, pp. 622-629, Jul. 2013.

[21] AKUBUDEA, V.C., NWAIGWEB, K.N., DINTWA, E. "Production of biodiesel from microalgae via nanocalyzed transesterification process: A review. 3”, Biotech., v. 7, n. 2, p. 99, Jun. 2017.

[22] THOAI, D.N. "Evaluation of Biodiesel Production Process by the Determining of the Total Glycerol Content in Biodiesel", In: International Conference on Alternative Energy in Developing Countries and Emerging Economies - Bangkok, Thailand, 2017 
[23] KELLY, P. Energy systems improvement based on endogenous and exogenous exergy destruction. Berlin, 2008.

[24] THIEDE, S. Energy Efficiency in Manufacturing System. Herrmann C, Kara S., editors. Springer; pp. 16, 2012.

[25] THAMLING, N., SEEFELDT, F., GLÖCKNER, U. Rolle und Bedeutung von Energieeffizienz und Energiedienstleistungen in KMU: Prognos AG, Basel, 2010.

[26] OLIVEIRA, E.L.B., LOPES N., DULLIUS, J., SEREFIN, M. “Análise exergética da produção de biodiesel a partir de óleo de cocção em escala laboratorial”, In: Anais do XI Salão de Iniciação Científica, Pontífica Universidade Católica do Rio Grande do Sul, Porto Alegre, 2010.

[27] ROSENA, M., DINCERA, I., KANOGLU, M. Role of exergy in increasing efficiency and sustainability and reducing environmental impact, Energy policy, 2007.

[28] RUIXIAN CAI, et al., Eds. "On exergetics, economics, and optimization of technical processes to meet environmental conditions", International Conference on Thermodynamic Analysis and Improvement of Energy Systems. Beijing, p. 453-460, 1997.

[29] MORAN, M.J., SHAPIRO, H.N. Fundamentos de Termodinamica para Engenharia. $6^{\circ}$ ed. LTC, 2009.

[30] KARAKATSANIS, G. Exergy and the economic process. European Geosciences Union General Assembly 2016, EGU Division Energy, Resources \& Environment, ERE. Energy Procedia 97, pp.51 -58, 2016. [31] AHERN, J. The exergy method of energy systems analysis. Wiley Inc., pp. 1-36, 1980.

[32] KARIMI, M. Exergy-based optimization of direct conversion of microalgae biomass to biodiesel. Journal of Cleaner Production, v. 141, pp 50-55, 2017.

[33] JAFARMADAR, S., NEMATI, P., "Multidimensional modeling of the effect of exhaust gas recirculation on exergy terms in a homogenous charge compression ignition engine fueled by diesel/biodiesel", Journal of Cleaner Production, v. 161, pp. 720-734.

[34] AYRES, R.U. "The Second Law, the Fourth Law, Recycling and Limits to Growth.Ecological”, Economics, v. 29, pp. 473-483, 1995.

[35] AMERICAN OIL CHEMIST'S SOCIETY-AOCS. Official Method TI 1a-64. Industrie oils and derivates, 1997.

[36] Acid value. Official Method Cd 3d-63. Official methods and recommended practices of the American Oil Chemists' Society, 5th ed. AOCS Press, Champaign. 1973.

[37] LUTZ, I.A. Métodos Físico-Químicos para Análise de Alimentos. São Paulo, p. 1004, 2004.

[38] AKERS, S.M., CONKLE, J. L., THOMAS, S.N., et al., Chem. Educ., n. 83, pp. 260, 2006.

[39] KOTAS, T.J. The Exergy Method of Thermal Plant Analysis. Florida: Krieger

[40] ARREDONDO, H.I.V. Avaliação exergética e exergo-ambiental da produção de biocombustíveis. São Paulo University, São Paulo, 2009.

[41] AYRES, R.U. The Second Law, the Fourth Law, Recycling and Limits to Growth. Ecological Economics, v. 29, pp. 473-483, 1995.

[42] FERREIRA, M.E.M. Análise exergo econômica da produção de biodiesel de babaçu obtido por via metílica e etílica . Universidade Federal do Paraná, Paraná, 2014.

[43] SILVA, M.M. Análise exergética da produção do biodiesel por mistura binária de sebo bovino e óleo de soja. Universidade Federal de Minas Gerais, Belo Horizonte, 2017.

\section{ORCID}

Antônio Alison da Silva Mamede Ada Amélia Sanders Lopes

Rosali Barbosa Marques Jackson Queiroz Malveira Maria Alexsandra de Sousa Rios https://orcid.org/0000-0002-2461-6120

https://orcid.org/0000-0003-0237-8595

https://orcid.org/0000-0001-8109-0826

https://orcid.org/0000-0002-6912-7937

https://orcid.org/0000-0002-3145-0456 